\begin{tabular}{|l|l|l||}
\hline \multicolumn{2}{|c|}{ PublisherInfo } \\
\hline \hline PublisherName & $:$ & BioMed Central \\
\hline \hline PublisherLocation & $:$ & London \\
\hline \hline PublisherImprintName & $:$ & BioMed Central \\
\hline \hline
\end{tabular}

\title{
Resuscitation, ethics and ICU
}

\begin{tabular}{|l|l|l||}
\hline \multicolumn{2}{|c|}{ ArticleInfo } \\
\hline \hline ArticleID & $:$ & 4092 \\
\hline \hline ArticleDOI & $:$ & $10.1186 /$ ccf-1999-1423 \\
\hline \hline ArticleCitationID & $:$ & 1423 \\
\hline \hline ArticleSequenceNumber & $:$ & 29 \\
\hline \hline ArticleCategory & $:$ & Paper Report \\
\hline ArticleFirstPage & $:$ & 1 \\
\hline \hline ArticleLastPage & $:$ & 4 \\
\hline \hline & & RegistrationDate : 1999-8-25 \\
\hline ArticleHistory & $:$ & OnlineDate \\
\hline \hline ArticleCopyright & $:$ & Current Science Ltd1999-8-25 \\
\hline \hline ArticleGrants & $:$ & \\
\hline \hline ArticleContext & $:$ & 130541111 \\
\hline \hline
\end{tabular}




\section{Keywords}

DNAR, ethics, ethics consultation, futility, hospital policy

\section{Comments}

The provision of an ethics consultation service is an aim that few hospitals can hope to attain. As this paper illustrated, most of the requests for consultations with the service were for ICU patients. This highlights the difficult decisions that have to be made in the ICU and may provide support for the further training of ICU staff in communication with patients and their families.

\section{Introduction}

Most medical decisions are shared between the patient and their physician. Occasionally however, their views may not agree, and at times decisions to withhold Cardio-pulmonary-resuscitation (CPR), known as unilateral do-not-attempt-resuscitation (DNAR) are made despite the objections of the patient or a surrogate. An important advance in this area has been the Houston Task Force model which aims to define the process by which futility decisions should be made. The Houston model requires the participation of patient or family and provides assistance by 'third parties' such as social workers, nurses, clergy and ethicists.

\section{Aims}

The authors aim to describe the role of an ethics consultation service in decisions to unilaterally withhold cardiopulmonary resuscitation.

\section{Methods}


The study retrospectively examined 31 cases which were referred to the ethics consultation team during a four year period at a major mid western USA teaching hospital. Seven ethics consultants (four physicians, one philosopher, one nurse and one attorney) carried out the ethics consultations. The consultation process followed a model of problem solving and mediation, the goal of which was to improve patient care. Data examined included demographic details of the cases and qualitative data such as the physician's intent and rationale for withholding CPR.

\section{Results}

Over the four-year period, 31 cases involving unilateral DNAR orders were identified. The proportion of cases was similar to the general hospital population in terms of age, gender and ethnicity. In all cases ethics consultation was requested because of a disagreement between physicians and the patient or the patient's surrogate. Ninety percent of the patients were in intensive care at the time of consultation. The ethics consultants believed that only 4 of the 31 patients had decision-making capacity at the time of consultation.

In all 31 cases, physicians intended to withhold CPR, and in 18 cases also intended to withdraw other treatments such as dialysis, pressor support or other medical treatment.

The consultation process involved physicians, ethics consultants and patient or patient's family. The ethics consultants aimed to act as mediators wherever possible, correcting misunderstandings, clarifying points of conflict and identifying areas of agreement that could be used to formulate a plan of treatment. It was not always possible to reach agreement on DNAR orders, and unilateral decisions were still made after attempts had been made using the ethics service.

The medical team intended to limit treatment in 12 cases because they felt the patient was unlikely to survive long enough to be released from the hospital, or (in 1 case) would have a poor quality of life, or both (in 13 cases). The ethics consultants agreed that CPR was not indicated in 21 cases. In six cases the consultants disagreed with the physicians, plan for unilateral DNAR. In five of these cases this was due to some disagreement about the patients' prognoses.

\section{Discussion}

This case series demonstrates the usefulness of ethics consultants in the decision making process that surrounds difficult and emotional decisions about whether to unilaterally withhold treatment. It is also of interest that a bilateral consensus was reached in approximately half the cases upon holding a family conference. This emphasizes the importance of communication and mediation, which is possible in all hospitals, not just those with an ethics consultation service.

In future, the authors feel that it is essential to clarify the effects of such DNAR orders on patient care. 


\section{References}

1. Casarett D, Siegler M: Unilateral do-not-attempt-resuscitation orders and ethics consultation: A case series. Crit Care Med. 1999, 27: 1116-1120

This PDF file was created after publication. 